\title{
Performance of polyaniline-derived Fe-N-C catalysts for oxygen reduction reaction in alkaline electrolyte
}

\author{
Xiang-Hui Yan, Gui-Rong Zhang, Bo-Qing Xu* \\ Innovative Catalysis Program, Key Lab of Organic Optoelectronics \& Molecular Engineering, Department of Chemistry, Tsinghua University, Beijing \\ 100084, China
}

\section{A R T I C L E I N F}

Article history:

Received 20 July 2013

Accepted 16 September 2013

Published 20 November 2013

\section{Keywords:}

Iron-nitrogen-carbon

Oxygen reduction reaction

Cathodic catalyst

Polyaniline

Iron-doping

Alkaline electrolyte

\begin{abstract}
A B S T R A C T
Without the presence of any precious metal, $\mathrm{Fe}-\mathrm{N}-\mathrm{C}$ materials derived from pyrolysis of polyaniline (PANI)/carbon $/ \mathrm{FeCl}_{3}$ mixtures are recognized as new catalysts for cathodic oxygen reduction reaction (ORR) in acidic electrolyte. How these Fe-N-C catalysts would perform in an alkaline electrolyte remains yet unknown. Reported here are assessments of the ORR performance of two Fe-N-C catalysts (Fe content: $3.4 \%$ and $5.9 \%$ ) in auqeous $\mathrm{KOH}$ by rotating disk electrode methods. Both Fe-N-C catalysts were found much more active than those metal-free $\mathrm{N}$-doped carbon materials in literature. Moreover, the ORR onset and half-wave potentials over both Fe- $\mathrm{N}-\mathrm{C}$ catalysts were respectively within 60 and $40 \mathrm{mV}$ from those delivered by conventional Pt/C catalyst and both Fe-N-C catalysts even showed much superior catalytic stability in chronoamperometric measurement. ORR on the present Fe-N-C catalysts proceeded predominantly via a four-electron transfer mechanism. This work would shed a light on Fe-N-C materials for ORR catalysis in alkaline fuel cells.
\end{abstract}

(C) 2013, Dalian Institute of Chemical Physics, Chinese Academy of Sciences. Published by Elsevier B.V. All rights reserved.
Recently, a wide variety of non-precious metal catalysts (NPMCs) for cathodic oxygen reduction reaction (ORR) have been developed including metal-macrocycle complexes and their pyrolyzed derivatives [1-4], metal oxides with or without being immobilized on supporting carbon materials [5,6], M-N-C ( $\mathrm{M}=\mathrm{Fe}$, Co, etc.) composites [7-12], and doped carbon materials [13-19]. Among these NPMCs, the M-N-C composites, generally prepared by pyrolyzing the mixture composed of a $\mathrm{N}$-containing organic precursor, a transition metal salt, and a carbon support, appear to attract an intense attention due to the great diversity of the $\mathrm{N}$-containing precursors and combinations between the different components, which give opportunities on performance enhancement and optimization.

While high activity for ORR of the M-N-C catalysts, especially the Fe-N-C ones, has been broadly studied in acidic electrolyte
[7-12], little attention has been paid to their catalytic performance in alkaline electrolyte. Alkaline polymer electrolyte fuel cells (APEFCs), known as the alkaline counterpart of the proton exchange membrane fuel cells (PEMFCs), are a subject of growing academic interest and industrial importance. Besides a faster ORR kinetics, APEFCs do not suffer from the metal dissolution or leach-out problem encountered with PEMFCs, making it possible to use very diverse NPMCs for electrode catalysts and to offer long-term catalyst durability [20]. Polyaniline-derived $\mathrm{Fe}-\mathrm{N}-\mathrm{C}$ catalysts, prepared by pyrolyzing a mixtures of polyaniline (PANI), $\mathrm{FeCl}_{3}$, and Ketjenblack, have been reported to be highly active for ORR in acidic electrolyte $[9,10]$, nonetheless, the catalytic performance of such Fe-N-C materials for ORR in alkaline electrolyte has not been investigated to the best of our knowledge.

\footnotetext{
*Corresponding author. Tel: +86-10-62792122; Fax: +86-10-62771149; E-mail: bqxu@mail.tsinghua.edu.cn This work was supported by the National Basic Research Program of China (973 Program, 2013CB933103). DOI: 10.1016/S1872-2067(12)60714-1 | http://www.sciencedirect.com/science/journal/18722067 | Chin. J. Catal., Vol. 34, No. 11, November 2013
} 
Herein we present the first application of PANI-derived Fe-N-C materials for ORR in alkaline electrolyte $(0.1 \mathrm{~mol} / \mathrm{L}$ $\mathrm{KOH}$ ). Our prepared PANI-derived Fe-N-C catalysts are found to offer a higher ORR activity than those metal-free doped carbon materials in alkaline electrolyte, being almost comparable to that of conventional Pt/C (E-TEK, $20 \mathrm{wt} \% \mathrm{Pt}$ ) catalyst in terms of onset potential ( $\left.E_{\text {onset }}\right)$, half-wave potential $\left(E_{1 / 2}\right)$, limiting current density $\left(U_{\mathrm{L}}\right)$, and number of transferred electrons $(n)$. Moreover, these PANI-derived Fe-N-C samples show better catalytic stability than the Pt/C catalyst. The ORR activity of these PANI-derived Fe-N-C catalysts is also measured in the acidic electrolyte for comparison with those in earlier literature.

PANI-derived Fe-N-C catalysts with two different Fe contents were prepared according to Refs. [9,10]. Briefly, aniline (AR, Tianjin YongDa Chemical Reagent Development Center, China) was dispersed in $\mathrm{HCl}$ solution $(0.5 \mathrm{~mol} / \mathrm{L})$ containing 0.4 g acid-treated Ketjenblack (EC-300J, AkzoNobel), followed by addition of proper amounts of ammonium peroxydisulfate (APS, AR, Beijing Modern Eastern Finechemical Co., Ltd., China) and ferric chloride (AR, Beijing Modern Eastern Finechemical Co., Ltd., China) to induce formation of PANI. The mixture was then vacuum-dried, followed by processing with three steps comprising of a first heat treatment up to $900{ }^{\circ} \mathrm{C}$ (HT1), an acid leaching (AL), and finally a second heat treatment at $900{ }^{\circ} \mathrm{C}$ (HT2). The samples obtained at the termination of HT2 were denoted PANI- $x$ Fe-C-HT2 $x$ refers to the final content of Fe in $w \mathrm{t} \%)$.

Various techniques were employed to characterize these PANI-Fe-C-HT2 samples, including low temperature $\mathrm{N}_{2}$ adsorption-desorption, transmission electron microscopy (TEM) combined with an energy dispersive X-ray probe (EDX), powder X-ray diffraction (XRD), and superconducting quantum interference device (SQUID). The final Fe content $(x$ wt $\%)$ were determined by inductively coupled plasma-atomic emission spectroscopy (ICP-AES) analysis of the solid residues from temperature-programmed oxidation (TPO) measurements up to $800{ }^{\circ} \mathrm{C}$. Electrochemical measurements were performed at room temperature in a three-electrode cell using a potentiostat/galvanostat Model 263A (PAR). A glassy carbon rotating disk electrode (GC-RDE, $0.19625 \mathrm{~cm}^{2}$ ) was employed as the working electrode. $\mathrm{Ag} / \mathrm{AgCl}$ (in $3.5 \mathrm{~mol} / \mathrm{L} \mathrm{KCl}$ ) and a Pt wire were used as the reference and counter electrodes, respectively. The catalyst ink was prepared by dispersing $3 \mathrm{mg}$ PANI-Fe-C-HT2 samples in $0.5 \mathrm{~mL}$ mixture of Nafion (5 wt\%) and deionized water $(1 / 9, \mathrm{~V} / \mathrm{V})$ under sonication. Measurement of the each catalyst was performed after applying and air-drying $20 \mu \mathrm{L}$ of the catalyst ink onto the polished electrode with a loading of $0.61 \mathrm{mg} / \mathrm{cm}^{2}$.

The catalytic ORR performance of the PANI-Fe-C-HT2 catalysts was studied by linear sweep voltammetry (LSV) using a rotating disk electrode (RDE) in an $\mathrm{O}_{2}$-saturated alkaline electrolyte $(0.1 \mathrm{~mol} / \mathrm{L} \mathrm{KOH})$, at a scan rate of $10 \mathrm{mV} / \mathrm{s}$ and a rotation rate of $1600 \mathrm{r} / \mathrm{min}$. For comparison, the activity of conventional Pt/C catalyst with a Pt loading of $20 \mu \mathrm{g} / \mathrm{cm}^{2}$ at the disk electrode was also measured under the same conditions. The polarization curves in Fig. 1(a) show that both PANI-Fe-C-HT2 catalysts exhibit higher ORR activity than the PANI-C-HT2 (without $\mathrm{Fe}$ ) catalyst in terms of the onset and half-wave potentials, and current density over the whole potential range. These results suggest that the introduction of Fe species could form more active $\mathrm{FeN}_{x}$ structures or generate a synergy between the co-existing Fe species and $\mathrm{N}$-doped carbon materials, to offer a better ORR activity [21-24]. Also listed in Table 1 are the limiting current density (measured from the plateaus of the polarization curves in Fig. 1(a)), onset and half-wave potentials on each individual catalyst. In spite of a higher Fe content, the PANI-5.9Fe-C-HT2 catalyst shows the same onset and
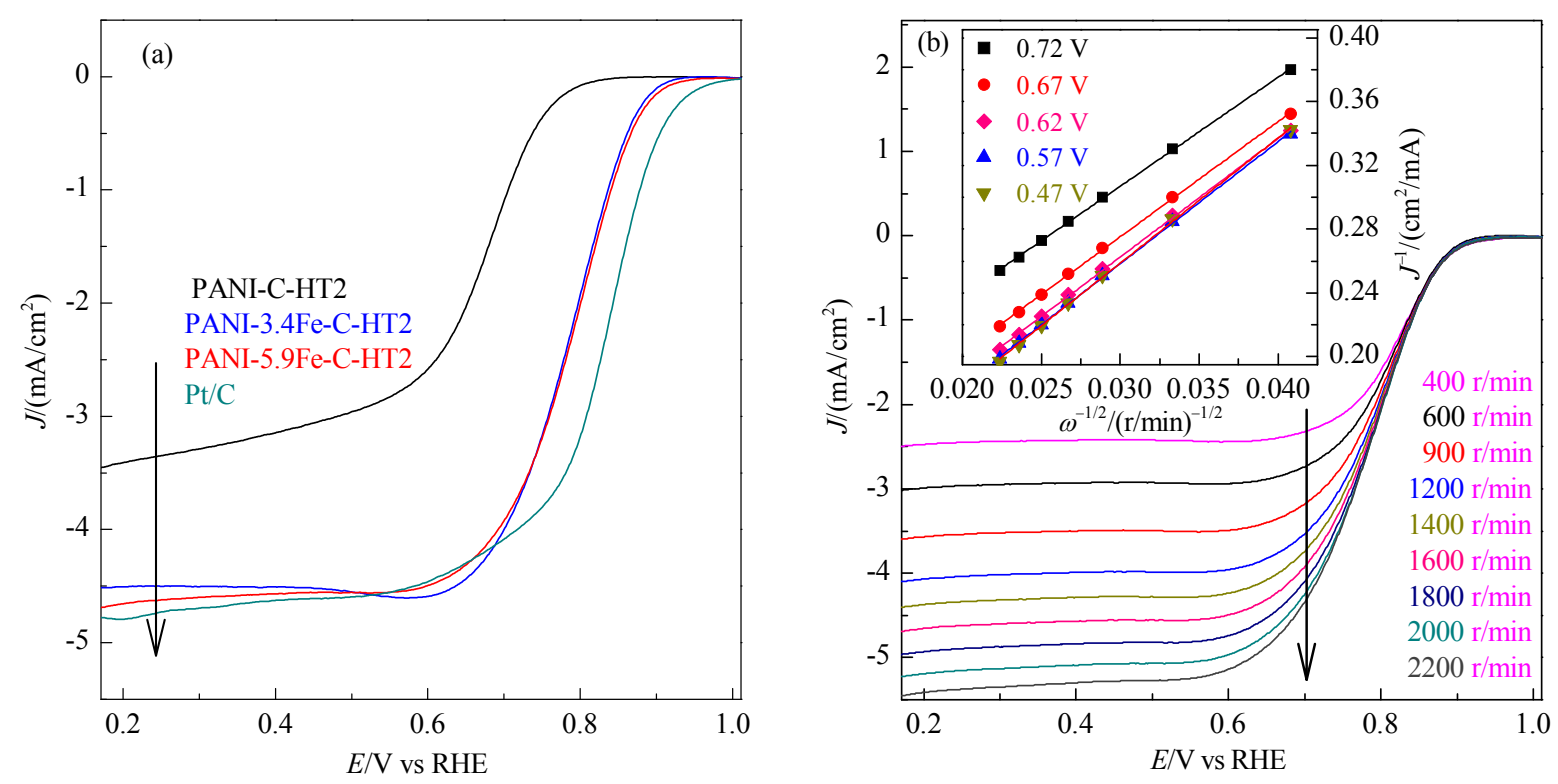

Fig. 1. (a) Polarization curves of Pt/C (E-TEK, $20 \% \mathrm{Pt})$ and PANI- $x$ Fe-C-HT2 $(x=0,4.3$, and $5.9 \mathrm{wt} \%)$ catalysts in $\mathrm{O}_{2}$-saturated $\mathrm{KOH}(0.1 \mathrm{~mol} / \mathrm{L})$ at a scan rate of $10 \mathrm{mV} / \mathrm{s}$ and a rotation rate of $1600 \mathrm{r} / \mathrm{min}$; (b) Polarization curves of the PANI-5.9Fe-C-HT2 catalyst at various rotation rates; the inset shows the corresponding Koutecky-Levich (K-L) plots $\left(J^{-1}\right.$ vs $\left.\omega^{-1 / 2}\right)$ at the indicated electrode potentials. 
Table 1

BET surface area and electrocatalytic properties of PANI-Fe-C-HT2 catalysts.

\begin{tabular}{|c|c|c|c|c|c|c|c|}
\hline \multirow{2}{*}{ Sample } & \multirow{2}{*}{$A_{\mathrm{BET}}\left(\mathrm{m}^{2} / \mathrm{g}\right)$} & \multirow{2}{*}{$E_{\text {onset }^{\mathrm{a}}}(\mathrm{V})$} & \multirow{2}{*}{$E_{1 / 2}{ }^{\mathrm{a}}(\mathrm{V})$} & \multirow{2}{*}{$J_{\mathrm{L}^{\mathrm{a}}}\left(\mathrm{mA} / \mathrm{cm}^{2}\right)$} & \multicolumn{3}{|c|}{ Number of transferred electrons ${ }^{\mathrm{b}}(n)$} \\
\hline & & & & & $0.72 \mathrm{~V}$ & $0.62 \mathrm{~V}$ & $0.47 \mathrm{~V}$ \\
\hline PANI-C-HT2 & 95 & $0.83(0.67)$ & $0.67(0.29)$ & - & 2.6 & 2.6 & 2.5 \\
\hline PANI-3.4Fe-C-HT2 & 96 & $0.93(0.85)$ & $0.79(0.53)$ & $4.50(4.51)$ & 4.0 & 3.7 & 3.5 \\
\hline PANI-5.9Fe-C-HT2 & 148 & $0.93(0.84)$ & $0.79(0.53)$ & $4.58(4.39)$ & 4.0 & 3.8 & 3.6 \\
\hline$\underline{\mathrm{Pt} / \mathrm{C}(\mathrm{E}-\mathrm{TEK}, 20 \mathrm{wt} \% \mathrm{Pt})}$ & - & 0.99 & 0.83 & 4.49 & 4.0 & 4.0 & 3.9 \\
\hline
\end{tabular}

a All potentials are given with respect to RHE. The $E_{\text {onset }}$ is defined as the potential at which the ORR generates a current density of $-0.02 \mathrm{~mA} / \mathrm{cm}^{2}$ [25], and the data in the parentheses refer to those obtained in the acidic electrolyte $\left(0.5 \mathrm{~mol} / \mathrm{L} \mathrm{H}_{2} \mathrm{SO}_{4}\right)$, assuming a complete ionization of $\mathrm{H}_{2} \mathrm{SO}_{4}$ (to $\mathrm{SO}_{4}{ }^{-}$ and $\mathrm{H}^{+}$) in the electrolyte.

${ }^{\mathrm{b}}$ Estimated according to the K-L plot.

half-wave potentials ( 0.93 and $0.79 \mathrm{~V}$, respectively) to the PANI-3.4Fe-C-HT2 catalyst, which are only 40-60 mV lower than those on conventional Pt/C catalyst. Furthermore, the limiting current densities produced on both PANI-Fe-C-HT2 catalysts are also comparable to that on $\mathrm{Pt} / \mathrm{C}$ catalyst. It should be noted that the ORR activity data for both the present PANI-Fe-C-HT2 catalysts (Table 1) are superior to those documented in literature for metal-free doped carbon materials [13-19].

Both PANI-Fe-C-HT2 catalysts were further investigated by LSV with the rotation rate varied from 400 to $2200 \mathrm{r} / \mathrm{min}$; the LSVs recorded in $\mathrm{O}_{2}$-saturated $\mathrm{KOH}(0.1 \mathrm{~mol} / \mathrm{L})$ for the PANI-5.9Fe-C-HT2 sample were presented in Fig. 1(b), as a representative. These measurements would enable an estimation of the number of transferred electrons $(n)$ per $\mathrm{O}_{2}$-reduction in the ORR process, according to the Koutecky-Levich (K-L) plot [26-28]. The inset depicts the corresponding K-L plots at various electrode potentials (0.72-0.47 V). These plots show good linearity and similar slopes, demonstrating a first-order reaction kinetics of ORR on the present PANI-Fe-C-HT2 catalysts. The slope of each K-L plot at a given potential for PANI-C-HT2 and both PANI-Fe-C-HT2 catalysts would give the number $n$ at that specific potential, which is summarized in Table 1. For comparison, the data for conventional Pt/C catalyst are also included in this table. The values of $n$ for ORR on the PANI-C-HT2 with no Fe are ca. 2.6 in the potential range of 0.72 to $0.47 \mathrm{~V}$. In contrast, the values of $n$ on both PANI-Fe-C-HT2 catalysts appeared sensitive to the potential, which were already as high as 3.5-3.6 even when the potential was as low as $0.47 \mathrm{~V}$ and were close to 4 when the potential became more positive. On the other hand, the values of $n$ on conventional Pt/C ( $n=3.9-4.0)$ were hardly affected by the operational potential, which is consistent with previous reports [6,29]. Assuming a mixed 2- and 4-electron $\mathrm{O}_{2}$-reduction chemistry, the numbers $n=$ ca. 2.6 on the PANI-C-HT2 would mean a $70 \%$ contribution from the 2-electron process while those $n=$ $3.6-4.0$ on the PANI-5.9Fe-C-HT2 should point to $80 \%-100 \%$ contribution from the 4-electron process. A $100 \% 4$-electron ORR process was actually realized when the potential was more positive than $0.67 \mathrm{~V}$ on both PANI-Fe-C-HT2 catalysts. These results indicate that the incorporation of Fe species could change the ORR process from a 2-electron to a dominant 4-electron transfer chemistry.

Durability of both PANI-Fe-C-HT2 catalysts with respect to conventional $\mathrm{Pt} / \mathrm{C}$ catalyst was assessed through chronoam- perometric measurement at $0.57 \mathrm{~V}$ in $\mathrm{O}_{2}$-saturated $\mathrm{KOH}(0.1$ mol/L) (Fig. 2). The activity loss for both PANI-Fe-C-HT2 catalysts during the test period (18000 s) was less than $10 \%$ whereas that for the Pt/C went as high as $24 \%$, which clearly demonstrate that the present PANI-Fe-C-HT2 catalysts are elecrtochemically much more stable than conventional $\mathrm{Pt} / \mathrm{C}$ catalyst.

TEM and EDX analyses (Fig. 3(a)) of the PANI-5.9Fe-C-HT2 catalyst revealed the presence of Fe entities (40-150 nm) encapsulated by graphitic carbon layers, which are in line with the eralier reports $[9,10]$. Further information on Fe entities in the PANI-Fe-C-HT2 catalysts can be extracted from the XRD and magnetization analyses. The two broad diffractions $(2 \theta=$ $25^{\circ}$ and $43.3^{\circ}$ ) in Fig. 3(b) signify the (002) and (101) diffractions of graphitic carbon, respectively. The presence of $\mathrm{Fe}_{1-x} \mathrm{~S}$ and $\mathrm{FeS}(x=0)$ is signified [30] by the diffractions at $2 \theta=29.9^{\circ}$, $33.7^{\circ}, 35.7^{\circ}, 43.2^{\circ}, 43.7^{\circ}, 47.2^{\circ}, 50.4^{\circ}, 53.0^{\circ}$, and $70.8^{\circ}$, and of metallic Fe crystallites at $2 \theta=44.7^{\circ}, 65.0^{\circ}$, and $82.3^{\circ}$. These Fecharacteristic signals increased with the content of $\mathrm{Fe}$ in the samples but diffractions for $\mathrm{Fe}_{3} \mathrm{O}_{4}$ (e.g., $2 \theta=56.2^{\circ}$ and $63.2^{\circ}$ ) were hardly detected. $\mathrm{Fe}_{1-x} \mathrm{~S}$ and metallic Fe appeared therefore to be the dominant Fe species in both PANI-Fe-C-HT2 samples. It is also observed in Fig. 3(b) that the ratio of metallic Fe to $\mathrm{Fe}_{1-x} \mathrm{~S}$ (according to the XRD peak intensity ratio of $\mathrm{Fe}(110)$ at $2 \theta=44.7^{\circ}$ to $\mathrm{FeS}(114)$ at $2 \theta=43.2^{\circ}$ ) in PANI-5.9Fe-C-HT2 was higher than that in PANI-3.4Fe-C-HT2, implying that a higher Fe

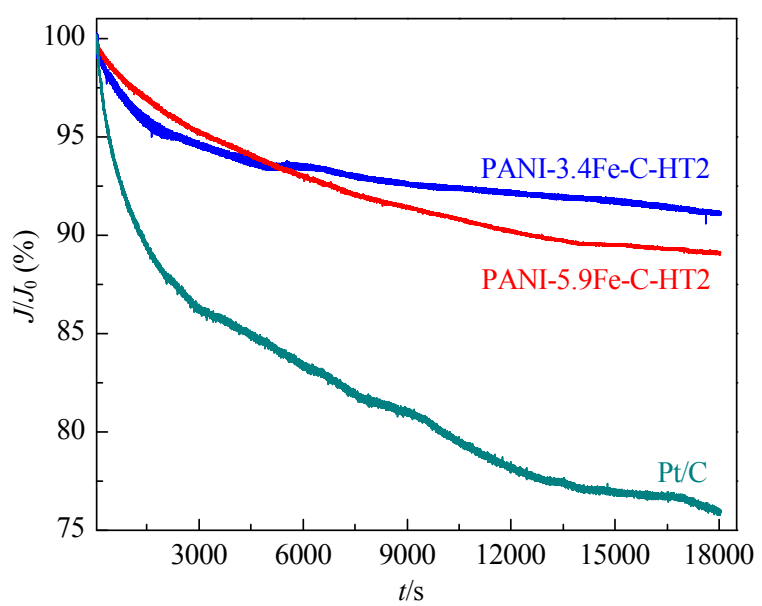

Fig. 2. Chronoamperometric responses at $0.57 \mathrm{~V}$ in $\mathrm{O}_{2}$-saturated $\mathrm{KOH}$ $(0.1 \mathrm{~mol} / \mathrm{L})$ at a rotation rate of $900 \mathrm{r} / \mathrm{min}$ of Pt/C and PANI-Fe-C-HT2 catalysts. 

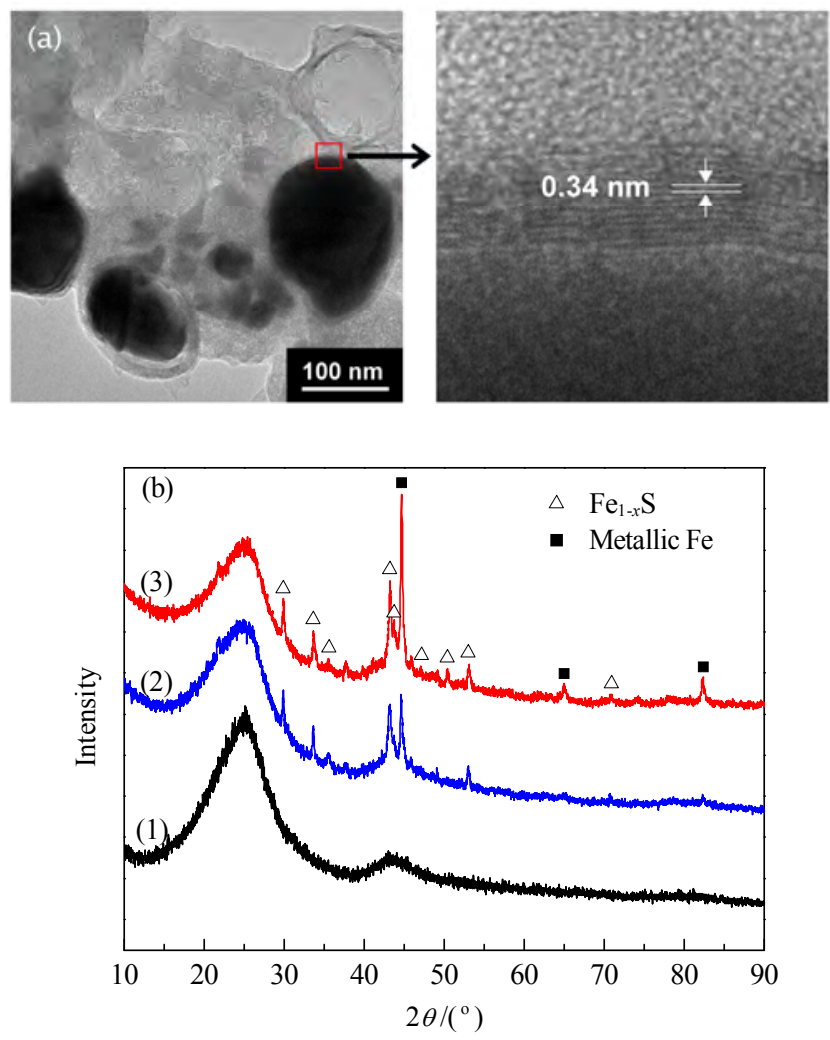

Fig. 3. (a) Representative TEM images of the PANI-5.9Fe-C-HT2 sample; (b) XRD patterns of PANI-C-HT2 (1), PANI-3.4Fe-C-HT2 (2), and PANI-5.9Fe-C-HT2 (3) samples.

content would favor the formation of more metallic Fe. This is at variance with the PANI-derived Fe-N-C catalyst (12 wt\% Fe, hereafter denoted as PANI-Fe-C-HT2-Ref) reported in Ref. [10], which showed no XRD signals for metallic Fe. The saturated magnetization for both PANI-Fe-C-HT2 samples, as measured by SQUID technique, was $4.55 \mathrm{emu} / \mathrm{g}$ for PANI-5.9Fe-C-HT2 and $2.23 \mathrm{emu} / \mathrm{g}$ for PANI-3.4Fe-C-HT2. This would be an indication that more metallic Fe crystallites were present in the former sample because the ferromagnetic metallic Fe was the predominant contributor to the magnetization, which is in agreement with the XRD results (Fig. 3(b)).

For comparison, the performance of the PANI-Fe-C-HT2 samples for ORR was also evaluated in acidic electrolyte 0.5 mol/ $\mathrm{L} \mathrm{H}_{2} \mathrm{SO}_{4}$ ) by cyclic voltammetry (CV) and LSV, as shown in Fig. 4. A pair of well-developed redox peaks emerged at ca. 0.64 $\mathrm{V}$ in the CVs for both PANI-Fe-C-HT2 catalysts in a $\mathrm{N}_{2}$-saturated $\mathrm{H}_{2} \mathrm{SO}_{4}(0.5 \mathrm{~mol} / \mathrm{L})$ (Fig. 4(a)), which would be related to a reversible one-electron process involving $\mathrm{Fe}^{3+} / \mathrm{Fe}^{2+}$ couple $[9,21]$ and were also present on the CVs of the PANI-Fe-C-HT2-Ref in Ref. [10]. These results seem to suggest that the present PANI-Fe-C-HT2 samples are qualitatively similar in electrochemical properties to the PANI-Fe-C-HT2-Ref in the acidic electrolyte. However, the polarization curves of ORR on both the present PANI-Fe-C-HT2 catalysts in $\mathrm{H}_{2} \mathrm{SO}_{4}(0.5 \mathrm{~mol} / \mathrm{L})$ (Fig.4(b)) and their derived limiting current densities, onset and half-wave potentials (see Table 1) failed unfortunately to match those of the PANI-Fe-C-HT2-Ref. We realized that the Fe content in the present PANI-5.9Fe-C-HT2 catalyst was only a half of that (12 wt\%) in the PANI-Fe-C-HT2-Ref. According to Refs. [9,10], increasing the heat treatment temperature of PANI-Fe-C-Ref from 400 to $900{ }^{\circ} \mathrm{C}$ would improve its ORR activity but decline significantly on further increasing the temperature to $1000{ }^{\circ} \mathrm{C}$. It was also found that metallic Fe was absent in the samples heat-treated below $900{ }^{\circ} \mathrm{C}$ but was present at $1000{ }^{\circ} \mathrm{C}$. Based on the above discussion, it can be learned that the presence of metallic Fe and the lower Fe content could be responsible for the lower activity of our PANI-Fe-C-HT2 samples in $\mathrm{H}_{2} \mathrm{SO}_{4}(0.5 \mathrm{~mol} / \mathrm{L})$ though other differences, including specific surface area, size and distribution of Fe species, cannot be completely ruled out at this stage. These results would hint that the structures of the present PANI-Fe-C-HT2 samples were somehow different from those of the PANI-Fe-C-HT2-Ref samples in Refs. [9,10] even though their preparation procedures were similar. Further study is therefore needed to uncover factors that would lead to well controlled structure and property of the smaples.

It would be argued that the presence of metallic Fe and the difference in Fe content might be the major factors responsible for the activity difference bewteen our PANI-Fe-C-HT2 catalysts and PANI-Fe-C-HT2-Ref in the acidic electrolyte as men-
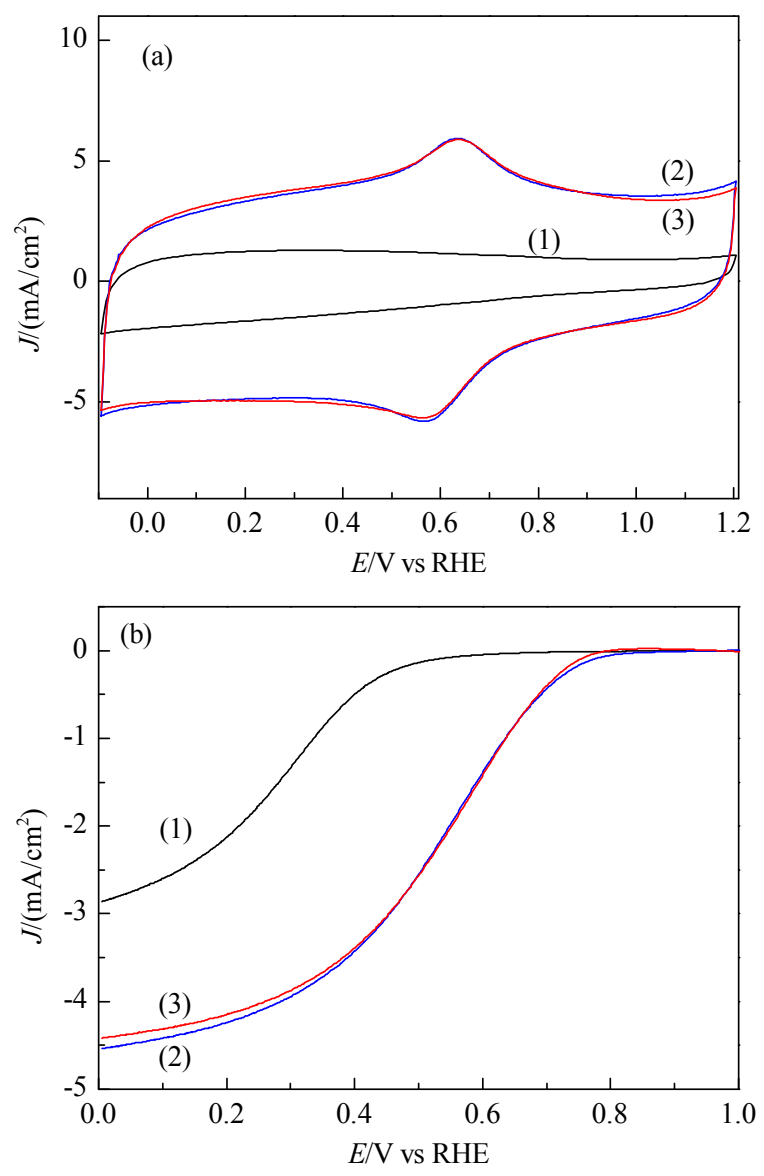

Fig. 4. (a) CVs in $\mathrm{N}_{2}$-saturated $\mathrm{H}_{2} \mathrm{SO}_{4}(0.5 \mathrm{~mol} / \mathrm{L})$ at a scan rate of 50 $\mathrm{mV} / \mathrm{s}$; (b) Polarization curves in $\mathrm{O}_{2}$-saturated $\mathrm{H}_{2} \mathrm{SO}_{4}(0.5 \mathrm{~mol} / \mathrm{L})$ at a scan rate of $10 \mathrm{mV} / \mathrm{s}$ and a rotation rate of $1600 \mathrm{r} / \mathrm{min}$ of the PANI-Fe-C-HT2 catalysts. (1) PANI-C-HT2; (2) PANI-3.4Fe-C-HT2; (3) PANI-5.9Fe-C-HT2. 
tioned above. Nevertheless, this does not seem to prevent the present PANI-Fe-C-HT2 catalysts from featuring the high activity and dominating 4-electron ORR chemistry in the alkaline electrolyte $(0.1 \mathrm{~mol} / \mathrm{L} \mathrm{KOH})$ (Fig. 1 and Table 1). These results also indicate that ORR proceeds more easily in the alkaline electrolyte than in the acidic electrolyte on the present PANI-Fe-C-HT2 catalysts. Therefore, prospect for the develoment of APEFCs using Fe-N-C and other NPMCs for cathodic ORR seems very promising.

In summary, our present data specified as onset potential, half-wave potential, limiting current density, and the number of transferred electrons, point to that the $\mathrm{Fe}-\mathrm{N}-\mathrm{C}$ materials are highly active catalysts for ORR in alkaline electrolyte, being superior to those metal-free carbon-based materials doped with heteroatoms and almost comparable to conventional Pt/C catalyst. Moreover, these Fe-N-C catalysts also displayed remarkable stability under the working conditions. ORR proceeded on both PANI-Fe-C-HT2 catalysts predominately through a 4-electron pathway. These findings, along with the activity comparison between the present PANI-Fe-C-HT2 catalysts and those PANI-Fe-C-HT2-Ref in eralier literature for ORR in the acidic electrolyte, reveal that finely tuning the chemical states and relative content of their involved Fe species by optimizing material compositions and complex preparation procedures could still provide a room for further improving the catalytic performance of $\mathrm{Fe}-\mathrm{N}-\mathrm{C}$ materials. This study helps to enrich the knowledge about the PANI-derived Fe-N-C catalysts, which would have important implication in making them competitive substitutes to Pt-based catalysts for cathodic ORR in APEFCs.

\section{References}

[1] Jasinski R J. Nature, 1964, 201: 1212

[2] Deng X Y, Zhang D Y, Wang X, Yuan X X, Ma Z F. Chin J Catal (邓选
英, 章冬云, 王昕, 原鲜霞, 马紫峰. 催化学报), 2008, 29: 519

[3] Liu R L, von Malotki C, Arnold L, Koshino N, Higashimura H, Baumgarten M, Müllen K. J Am Chem Soc, 2011, 133: 10372

[4] Meng H, Larouche N, Lefèvre M, Jaouen F, Stansfield B, Dodelet J P. Electrochim Acta, 2010, 55: 6450

[5] Meadowcroft D B. Nature, 1970, 226: 847

[6] Liang Y Y, Li Y G, Wang H L, Zhou J G, Wang J, Regier T, Dai H J. Nat Mater, 2011, 10: 780

[7] Byon H R, Suntivich J, Shao-Horn Y. Chem Mater, 2011, 23: 3421

[8] Lefèvre M, Proietti E, Jaouen F, Dodelet J P. Science, 2009, 324: 71

[9] Wu G, More K L, Johnston C M, Zelenay P. Science, 2011, 332: 443

[10] Wu G, Johnston C M, Mack N H, Artyushkova K, Ferrandon M, Nelson M, Lezama-Pacheco J S, Conradson S D, More K L, Myers D J, Zelenay P. J Mater Chem, 2011, 21: 11392

[11] Choi J Y, Hsu R S, Chen Z W. J Phys Chem C, 2010, 114: 8048

[12] Li X G, Liu G, Popov B N.J Power Sources, 2010, 195: 6373

[13] Yang S B, Feng X L, Wang X C, Müllen K. Angew Chem Int Ed, 2011, 50: 5339

[14] Zheng Y, Jiao Y, Chen J, Liu J, Liang J, Du A J, Zhang W M, Zhu Z H, Smith S C, Jaroniec M, Lu G Q, Qiao S Z. J Am Chem Soc, 2011, 133: 20116

[15] Liu Z W, Peng F, Wang H J, Yu H, Zheng W X, Yang J. Angew Chem Int $E d, 2011,50: 3257$

[16] Yang D S, Bhattacharjya D, Inamdar S, Park J, Yu J S. J Am Chem Soc, 2012, 134: 16127

[17] Yao Z, Nie H G, Yang Z, Zhou X M, Liu Z, Huang S M. Chem Commun, 2012, 48: 1027

[18] Sheng Z H, Gao H L, Bao W J, Wang F B, Xia X H. J Mater Chem, 2012, 22: 390

[19] Li Q Q, Zhang S, Dai L M, Li L S. J Am Chem Soc, 2012, 134: 18932

[20] Spendelow J S, Wieckowski A. Phys Chem Chem Phys, 2007, 9: 2654

[21] Lefèvre M, Dodelet J P, Bertrand P. J Phys Chem B, 2002, 106: 8705

[22] Jaouen F, Proietti E, Lefèvre M, Chenitz R, Dodelet J P, Wu G, Chung H T, Johnston C M, Zelenay P. Energy Environ Sci, 2011, 4: 114

[23] Chen Z W, Higgins D, Yu A P, Zhang L, Zhang J J. Energy Environ Sci, 2011, 4: 3167

\section{Graphical Abstract}

Chin. J. Catal., 2013, 34: 1992-1997 doi: 10.1016/S1872-2067(12)60714-1

Performance of polyaniline-derived Fe-N-C catalysts for oxygen reduction reaction in alkaline electrolyte

Xiang-Hui Yan, Gui-Rong Zhang, Bo-Qing Xu*

Tsinghua University
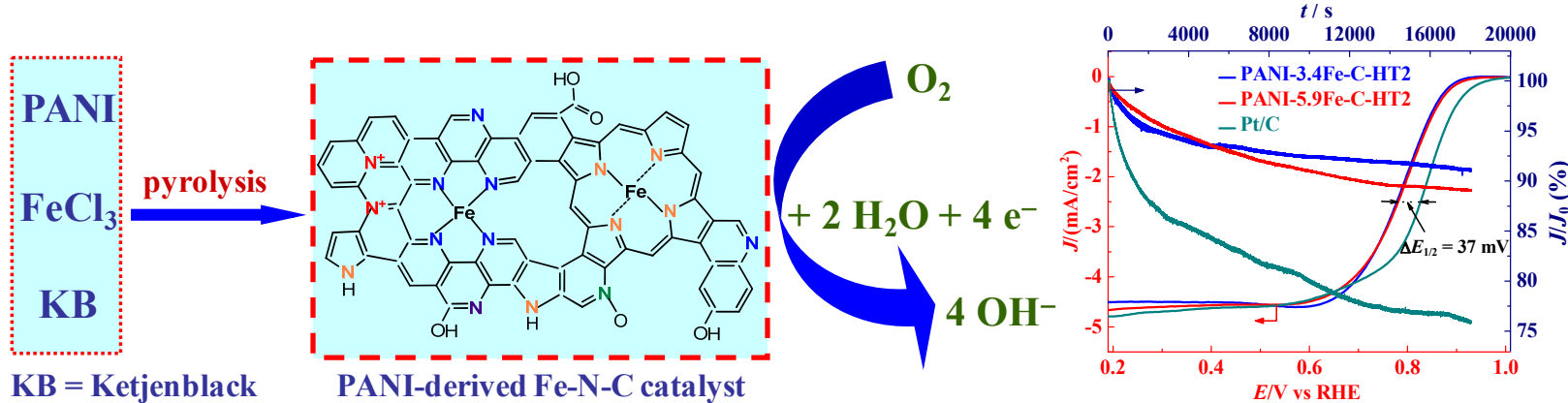

The onset and half-wave potentials of PANI-derived Fe-N-C catalysts are found close to conventional Pt/C catalyst for cathodic ORR in alkaline electrolyte; the Fe-N-C catalysts show even significantly higher stabilities. 
[24] Parvez K, Yang S B, Hernandez Y, Winter A, Turchanin A, Feng X L, Müllen K. ACS Nano, 2012, 6: 9541

[25] Chokai M, Taniguchi M, Moriya S, Matsubayashi K, Shinoda T, Nabae Y, Kuroki S, Hayakawa T, Kakimoto M, Ozaki J, Miyata S. J Power Sources, 2010, 195: 5947

[26] Bard A J, Faulkner L R. Electrochemical Methods: Fundamentals and Applications. 2nd Ed. New York: Wiley, 2001
[27] Feng Y Y, Zhang G R, Ma J H, Liu G, Xu B Q. Phys Chem Chem Phys, 2011, 13: 3863

[28] Zhang G R, Xu B Q. Chin J Catal (张贵荣, 徐柏庆. 催化学报), 2013, 34: 942

[29] Markovic N M, Gasteiger H A, Ross P N Jr. J Phys Chem, 1996, 100: 6715

[30] Hyun S W, Shim I B, Kim C S. IEEE Trans Magn, 2008, 44: 2948

\title{
聚苯胺衍生 $\mathrm{Fe}-\mathrm{N}-\mathrm{C}$ 催化剂在碱性电解质中对氧还原反应的催化性能
}

\author{
严祥辉, 张贵荣, 徐柏庆 ${ }^{*}$ \\ 清华大学化学系, 有机光电子与分子工程教育部重点实验室, 北京 100084
}

摘要: 经过热解聚苯胺、碳和 $\mathrm{FeCl}_{3}$ 的混合物制备的 $\mathrm{Fe}-\mathrm{N}-\mathrm{C}$ 材料在酸性电解质中对氧还原反应表现出高的催化活性; 由于材料中 不存在任何贵金属, 因而被认为是一类新型非贵金属氧还原催化剂. 然而这类催化剂在碱性电解质中催化氧还原反应的性能如 何尚不清楚. 本文使用旋转圆盘电极技术考察了制备的两个Fe-N-C催化剂在 KOH水溶液中催化氧还原反应性能, 发现这两个催 化剂表现出比无金属的 $\mathrm{N}$ 掺杂碳材料更高的活性. 与商业 $\mathrm{Pt} / \mathrm{C}$ 催化剂相比, 它们催化氧还原反应的起始电势和半波电势分别仅低 60 和 $40 \mathrm{mV}$ 左右, 计时电流测试表明, 它们比 Pt/C催化剂显示出更好的稳定性. 此外, 在这两个Fe-N-C催化剂上的氧还原反应主要 遵循四电子途径. 本工作显示, Fe-N-C材料有望用于碱性燃料电池氧还原反应催化剂.

关键词: 铁-氮-碳; 氧还原反应; 阴极催化剂; 聚苯胺; 铁掺杂; 碱性电解质

收稿日期: 2013-07-20. 接受日期: 2013-09-16. 出版日期: 2013-11-20.

*通讯联系人. 电话: (010)62773208; 传真: (010)62771149; 电子信箱: bqxu@mail.tsinghua.edu.cn

基金来源：国家重点基础研究发展计划(973计划, 2013CB933103).

本文的英文电子版由Elsevier出版社在ScienceDirect上出版(http://www.sciencedirect.com/science/journal/18722067). 